\title{
Organometallic Fragments in Microporous Solids: Intrazeolite Chemistry of (Cyclooctatetraene)iron Tricarbonyl
}

\author{
Aticha Borvornwattananont, Karin Moller, and Thomas Bein* \\ Department of Chemistry, University of New Mexico, Albuquerque, New Mexico 87131 \\ (Received: August 5, 1988; In Final Form: October 20, 1988)
}

\begin{abstract}
The intrazeolite reactivity of $(\mathrm{COT}) \mathrm{Fe}(\mathrm{CO})_{3}(\mathrm{COT}=$ cyclooctatetraene) [1] in faujasites having different levels of Bronsted acidity was examined with extended X-ray absorption fine structure, vibrational, and temperature programmed desorption/mass spectrometric techniques. The data show that the precursor complex [1] associates with $\mathrm{Na}-\mathrm{Y}$ zeolite, resulting in symmetry changes of the $\mathrm{Fe}(\mathrm{CO})_{3}$ fragment while 1 remains chemically intact. If $(\mathrm{COT}) \mathrm{Fe}(\mathrm{CO})_{3}$ is adsorbed into highly acidic $\mathrm{H}-\mathrm{Y}$ zeolite at room temperature, bicyclo[5.1.0]octadienyliron tricarbonyl cation is formed in a clean reaction. This reaction corresponds to the protonation of 1 with noncoordinating acids in homogeneous solution. At elevated temperatures, the carbonyl ligands are cleaved off and the remaining organo-iron fragment is anchored to framework oxygens of the large zeolite supercages.
\end{abstract}

\section{Introduction}

Many organometallic complexes have successfully been used in homogeneous catalysis. Often these catalyst systems are highly selective and allow mild reaction conditions to be used. However, difficult separation of the catalyst from the products or deactivation due to irreversible structural changes can compromise the benefits of homogeneous catalytic systems. In an attempt to combine the advantages of both homogeneous and heterogeneous systems, molecular catalysts have in the past been supported on various metal oxides. A wide range of transition-metal $\pi$-allyl, cyclopentadienyl $(\mathrm{Cp})$, carbonyl, and olefin derived catalyst precursors have been prepared during the past decade, including group IV, VI, and VIII metal species supported on amorphous oxides. ${ }^{1-5}$

In contrast to classical amorphous catalyst supports, the crystalline pore structure of zeolites offers a unique potential to control substrate access through diffusional selectivity and to modify catalytic transition states. The present study is part of a research program aimed at the synthesis of well-defined, stable hybrid catalysts by anchoring transition-metal species into zeolite supports. We explore the reactivity of transition-metal complexes in acid forms of zeolites. Anchoring of metal species into the zeolite cavities can in principle be achieved by substituting leaving groups at the transition-metal complex with zeolite oxygen. As a basis for the rational design of zeolite-based hybrid catalysts, we study the different relative reactivities and stabilities of ligands at a metal center with respect to the bridged intrazeolite hydroxyls $(\mathrm{ZOH})$. In this study, the intrazeolite reactivities of cyclooctatetraene (COT) and carbonyl ligands of (COT) $\mathrm{Fe}(\mathrm{CO})_{3}[1]$ have been examined.

The protonation of $(\mathrm{COT}) \mathrm{Fe}(\mathrm{CO})_{3}$ in homogeneous solution has been well studied. Key reactions are summarized in Scheme $1 .^{6-9}$ It has been reported that by treating 1 with a noncoordinating acid at $153 \mathrm{~K}$ the ring-protonated complex [2] is formed (see Scheme I), which rearranges to bicyclo[5.1.0] octadienyliron tricarbonyl cation (or homotropylium iron tricarbonyl) [3] at 213 $\mathrm{K}$. However, the reaction of 1 with $\mathrm{HCl}$ at $273 \mathrm{~K}$ yielded 4 instead

(1) Yermakov, Y. I. Catal. Rev. Sci. Eng. 1976, 13, 77.

(2) Ward, M. D.: Schwartz, J. J. Mol. Catal. 1981, 11, 397

(3) Spek, T. G.; Scholten, J. F. J. Mol. Catal. 1977, 3, 81

(4) Foley, H. C.; DeCanio, S. J.; Tau, K. D.; Chao, K. J.; Onuferko, J. H.; Dybowsky, C.; Gates, B. C. J. Am. Chem. Soc. 1983, 105, 3074.

(5) Gates, B. C. Metal Clusters, Moskovits, M., Ed.; Wiley: New York, 1986; p 283.

(6) Davison, A.; McFarlane, W.; Pratt, L.; Wilkinson, G. J. Chem. Soc. 1962, 4821 .

(7) Brookhart, M.; Davis, E. R.; Harris, L. J. Am. Chem. Soc. 1972, 94 , 7853.

(8) Olah, G. A.; Liang, G.; Yu, S. J. Org. Chem. 1977, 42, 4262.

(9) Charles, A. D.; Diversi,' P.; Johnson, B. F. G.; Lewis, J. J. Organomet. Chem. 1976, 116, C25.
SCHEME I: Summary of Chemistry of (COT) $\mathrm{Fe}(\mathrm{CO})_{3}$ and Related Compounds

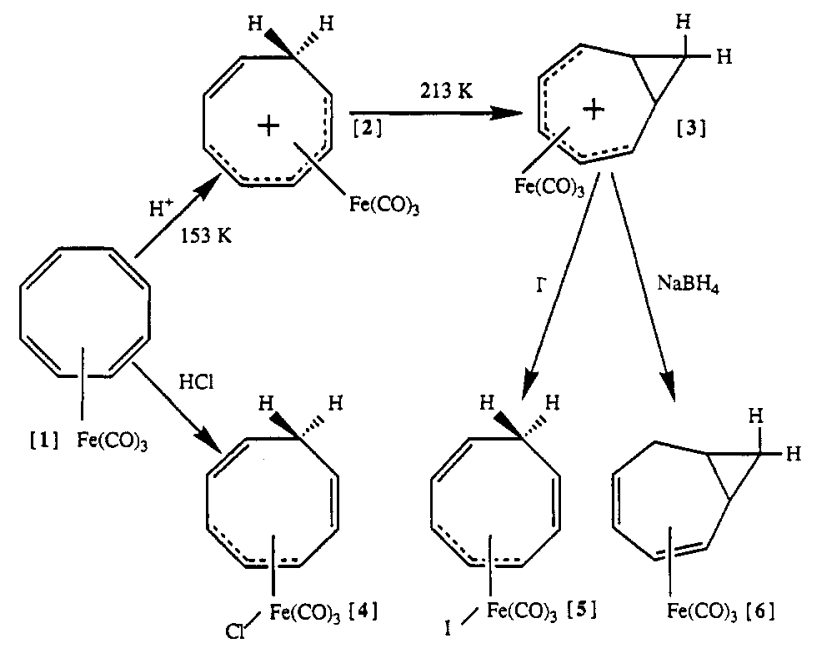

of 3. It was proposed that the monocyclic cation [2] might initially be formed and immediately be attacked by $\mathrm{Cl}^{-}$at the $\mathrm{Fe}$ center before the rearrangement of $\mathbf{2}$ to $\mathbf{3}$ could take place.

Proton-exchanged zeolites represent solid acids of proton activity comparable to strong mineral acids $\left(\mathrm{p} K_{\mathrm{a}}<-3\right) .{ }^{10}$ Similar to solution chemistry, the COT ligand can be expected to be protonated in the zeolite solid acid. The cationic complex is stabilized by electrostatic interaction with the negatively charged intrazeolite oxygen surface. This process represents the first step of an "anchoring" sequence, which in this case is completed by substitution of the less stable carbonyls with zeolite oxygen ligands:

$$
\text { (COT) } \mathrm{Fe}(\mathrm{CO})_{3} \underset{-3 \mathrm{CO}}{\stackrel{\mathrm{ZOH}, n \mathrm{ZO}}{\longrightarrow}} \mathrm{H}(\mathrm{COT}) \mathrm{Fe}(\mathrm{OZ})_{n+1}
$$

Another example of this general concept is the chemistry of $\left[\mathrm{CpFe}(\mathrm{CO})_{2}\right]_{2}$ and ferrocene adsorbed into zeolite $\mathrm{Y}$ supports. ${ }^{11}$ We have found that depending on the amount of acid groups present in the zeolite cages the dimer was either protonated to $\left[\mathrm{CpFe}(\mathrm{CO})_{2}\right]_{2} \mathrm{H}^{+}$or oxidatively cleaved to $\mathrm{CpFe}(\mathrm{CO})_{3}{ }^{+}$. Upon heat treatment a zeolite-anchored fragment $\mathrm{CpFe}(\mathrm{OZ})_{n}(\mathrm{OZ}=$ zeolite oxygen) remained, representing a potential reactive center in the zeolite cage. These studies form a basis for the development of well-defined hybrid catalysts based on zeolite hosts.

The identification of molecular species in microporous solids typically requires a combination of specialized analytical tech-

(10) Beaumont, R.; Barthomeuf, D.; Trambouze, Y. Adv. Chem. Ser. 1971, No. 102, 327 .

(11) Moller, K; Borvornwattananont, A.; Bein, T. J. Phys. Chem., in press 
TABLE I: Sample Compositions

\begin{tabular}{cll}
\hline sample & \multicolumn{1}{c}{ support } & cations present \\
\hline $\mathrm{Na}-\mathrm{Y} / \mathrm{COT}$ & Linde LZ-Y52 & $\mathrm{Na}^{+}$ \\
$\mathrm{H} 2-\mathrm{Y} / \mathrm{COT}$ & Linde LZ-Y52 $\left(2 \mathrm{H}^{+} / \mathrm{sc}\right)$ & $\mathrm{H}^{+}$and $\mathrm{Na}^{+}$ \\
$\mathrm{H} 6-\mathrm{Y} / \mathrm{COT}$ & Linde LZ-Y62 $\left(6 \mathrm{H}^{+} / \mathrm{sc}\right)$ & $\mathrm{H}^{+}$ \\
$\mathrm{H}-\mathrm{Y} / \mathrm{COT}$ & Linde LZ-Y72 & $\mathrm{H}^{+}$ \\
& & \\
& &
\end{tabular}

niques. We use X-ray absorption spectroscopy (EXAFS) and in situ vibrational spectroscopy coupled to TPD-MS to elucidate the intrazeolite chemistry of 1 . In combination, these methods provide detailed insight into the local structural changes and surface chemistry of the intrazeolite species involved.

\section{Experimental Section}

Sample Preparation. Four different supports derived from zeolite $\mathrm{Y}$ were used in this study: $\mathrm{Na}-\mathrm{Y}$ (commercial Linde LZ-Y 52, $\left[\mathrm{Na}_{57} \mathrm{Al}_{57} \mathrm{Si}_{135} \mathrm{O}_{384}\right] \cdot 235 \mathrm{H}_{2} \mathrm{O}$ ), partially proton exchanged $\mathrm{H} 2-\mathrm{Y}\left(2 \mathrm{H}^{+} / \mathrm{sc}, \mathrm{sc}=\right.$ zeolite supercage $)$ derived from LZ-Y 52 via ion exchange with $2 \mathrm{NH}_{4}^{+} / \mathrm{sc}$, highly acidic $\mathrm{H}^{-}-\mathrm{Y}\left(6 \mathrm{H}^{+} / \mathrm{sc}\right)$ derived from Linde LZ-Y62 $\left[\left(\mathrm{NH}_{4}\right)_{45} \mathrm{Na}_{10} \mathrm{Al}_{55} \mathrm{Si}_{137} \mathrm{O}_{384}\right] \cdot 235 \mathrm{H}_{2} \mathrm{O}$, and proton-exchanged, thermally stabilized zeolite Linde LZ-Y72 with a $\mathrm{Si} / \mathrm{Al}$ ratio of 2.55 . Heating the ammonium-exchanged zeolites under vacuum at $1 \mathrm{~K} / \mathrm{min}$ up to $700 \mathrm{~K}$ resulted in the desired acid form of the zeolites. The dehydrated zeolites were kept in a glovebox (oxygen content $<2 \mathrm{ppm}$ ) prior to subsequent treatments. The dry zeolites were loaded with an average stoichiometry of 1 molecule of $(\mathrm{COT}) \mathrm{Fe}(\mathrm{CO})_{3}$ [1] per supercage by stirring a slurry of $0.500 \mathrm{~g}$ of zeolite with the required amounts of complex [1] in $50 \mathrm{~mL}$ of hexane for $12 \mathrm{~h}$ under nitrogen. The solvent was removed by brief vacuum filtration on a frit. Sample compositions are listed in Table I. The loading of the zeolite system with the organometallic complex was followed by decoloration of the hexane solution.

FTIR-TPD-MS. FTIR data were taken with a Mattson Polaris spectrometer at $4-\mathrm{cm}^{-1}$ resolution. Each sample was deposited as a thin dispersion on an IR-transparent $\mathrm{Si}$ wafer and introduced into a heatable in situ cell with $\mathrm{CaF}_{2}$ windows under nitrogen atmosphere in the glovebox. The cell was connected to a vacuum manifold pumped by a turbomolecular pump and to a quadrupole mass spectrometer (Dycor M200, 1-200 amu). Molecular sieve pumps were used as backup pumps for the turbopump in order to eliminate hydrocarbon contamination. Including the dominant residual $\mathrm{H}_{2}$ and $\mathrm{He}$, a base pressure of $10^{-7}$ Torr was obtained. The samples were evacuated until the total pressure was $10^{-6}$ Torr before being heated. Up to five mass fragments could be monitored as a function of time/temperature in the TPD-MS experiments. The iron-containing-zeolite samples were heated at ca. $1 \mathrm{~K} / \mathrm{min}$ up to $460 \mathrm{~K}$ (actual sample temperature, measured at the silicon support wafer) while simultaneously monitoring the FTIR and mass spectra. Additional TPD-MS data were obtained with a Finnigan Mat 4500 series GC/MS spectrometer by scanning masses $20-600 \mathrm{amu}$ while heating from 323 to $673 \mathrm{~K}$ at a heating rate of $23 \mathrm{~K} / \mathrm{min}$.

EXAFS. EXAFS measurements were performed at NSLS (Brookhaven National Laboratory) at beam line X-11 A with a stored electron energy of $2.5 \mathrm{GeV}$ and ring currents between 60 and $110 \mathrm{~mA}$. Fe K edge data at $7112 \mathrm{eV}$ were collected at about $100 \mathrm{~K}$ in transmission using a $\mathrm{Si}(111)$ monochromator. The powdered samples were sealed against access of air in a 1:1 eicosane/octadecane mixture and kept under nitrogen until EXAFS data were collected. The sample thickness was adjusted such that the total absorption did not exceed a value of 2 to ensure an optimal signal-to-noise ratio.

The EXAFS data were analyzed following standard procedures. $^{12}$ Phase functions and backscattering amplitudes were extracted from the following references (atom pairs in parentheses): $\mathrm{Fe}^{\mathrm{III}}(\mathrm{acac})_{3}(\mathrm{Fe}-\mathrm{O})$, ferrocene $(\mathrm{Fe}-\mathrm{C})$, and $\mathrm{FeC}_{3}-$

(12) Lee, P. A.; Citrin, P. H.; Eisenberger, P.; Kincaid, B. M. Rev. Mod Phys, 1981, 53, 769

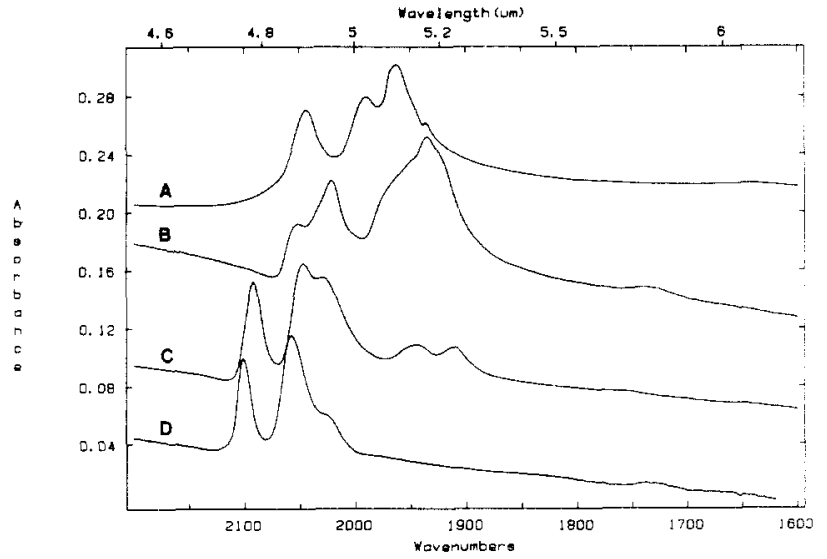

Figure 1. FTIR spectra of (COT) $\mathrm{Fe}(\mathrm{CO})_{3}$ in different media at room temperature: (A) in $\mathrm{KBr}$, (B) adsorbed into $\mathrm{Na}-\mathrm{Y}$, (C) adsorbed into $\mathrm{H} 2-\mathrm{Y}$, (D) adsorbed in to $\mathrm{H} 6-\mathrm{Y}$

$\mathrm{H}_{5}(\mathrm{CO})_{3} \mathrm{Cl}(\mathrm{Fe}-\mathrm{CO})$. K-edge background removal was accomplished by applying a Victoreen fit to the preedge region and a cubic spline function to the EXAFS data. Normalization to an $\mathrm{Fe}$ atom basis was performed by using the step height of the absorption edge. References and samples were processed as similarly as possible to avoid artifacts.

EXAFS measurements were performed on two samples: proton-exchanged zeolite Linde LZ-Y72 was loaded with 1 molecule of $(\mathrm{COT}) \mathrm{Fe}(\mathrm{CO})_{3}$ per supercage at room temperature (sample $\mathrm{H}-\mathrm{Y} / \mathrm{COT}-\mathrm{R}$ ). Five hundred milligrams of sample $\mathrm{H}-\mathrm{Y} / \mathrm{COT}-\mathrm{R}$ was heated in a quartz reactor under vacuum for $10 \mathrm{~h}$ at $373 \mathrm{~K}$ to give the second sample $\mathrm{H}-\mathrm{Y} / \mathrm{COT}-373$.

\section{Results}

Adsorption of $(\mathrm{COT}) \mathrm{Fe}(\mathrm{CO})_{3}$ into Zeolite Supports at Room Temperature. The IR spectra of the $\mathrm{CO}$ stretching region of $(\mathrm{COT}) \mathrm{Fe}(\mathrm{CO})_{3}[\mathbf{1}]$ in $\mathrm{KBr}$ and in different zeolite supports at room temperature are shown in Figure 1. The main frequencies are summarized in Table II. Upon loading 1 into dehydrated $\mathrm{Na}-\mathrm{Y}$ (sample $\mathrm{Na}-\mathrm{Y} / \mathrm{COT}$, Figure 1B), at least five bands are observed. These bands are believed to be due to two different absorption modes of 1 in $\mathrm{Na}-\mathrm{Y}$. The features of the dominant contribution are comparable to that of $(\mathrm{COT}) \mathrm{Fe}(\mathrm{CO})_{3}$ in a $\mathrm{KBr}$ pellet. The two strongest bands are shifted to lower frequencies $\left(2043,1963 \rightarrow 2021,1935 \mathrm{~cm}^{-1}\right.$; Figure 1 A,B) which is probably caused by a moderate interaction of the complex with the zeolite framework. This species is labeled I. The asymmetric peak shape of the $\mathrm{CO}$ band at $1935 \mathrm{~cm}^{-1}$ and the residual bands at elevated temperature (Figure 3 ) suggest the presence of a second species labeled Il characterized by $\mathrm{Na}^{+} \ldots \mathrm{OC}$ interaction with zeolite sodium cations (see Discussion). In the partially proton-exchanged sample $\mathrm{H} 2-\mathrm{Y} / \mathrm{COT}$, again two carbonyl species are detected. The strongest bands at 2092 and $2047 \mathrm{~cm}^{-1}$ are assigned to the homotropylium iron tricarbonyl ion [3] (reported 2108 and 2055 $\mathrm{cm}^{-16}$ ). The second compound (1945 and $1912 \mathrm{~cm}^{-1}$ ) is believed to be similar to the second absorption mode of 1 in sample $\mathrm{Na}-$ $\mathrm{Y} / \mathrm{COT}$ (species II) convoluted in the asymmetric peak at 1935 $\mathrm{cm}^{-1}$ (see Discussion).

An apparently complete reaction of $(\mathrm{COT}) \mathrm{Fe}(\mathrm{CO})_{3}$ to the homotropylium complex [3] occurs in the highly proton exchanged zeolite support H6-Y (sample H6-Y/COT, Figure 1D) as indicated by the strong bands at 2101 and $2058 \mathrm{~cm}^{-1}$. The shoulder at $2028 \mathrm{~cm}^{-1}$ is probably caused by a lower symmetry of 3 in the zeolite host compared to solution or by a small amount of an unknown byproduct. The formation of 3 which was observed only in acid zeolite samples indicates that zeolite framework hydroxyls behave in a manner similar to that of protons in solution. The band positions of sample $\mathrm{H6}-\mathrm{Y} / \mathrm{COT}$ at 2101 and $2058 \mathrm{~cm}^{-1}$ are almost identical with those reported for 3 in the literature. ${ }^{6}$ The small shift of the $\mathrm{CO}$ bands to lower energy observed for the same complex in sample $\mathrm{H} 2-\mathrm{Y} / \mathrm{COT}$ are believed to be caused by the sodium cations present in that sample. This interaction between 


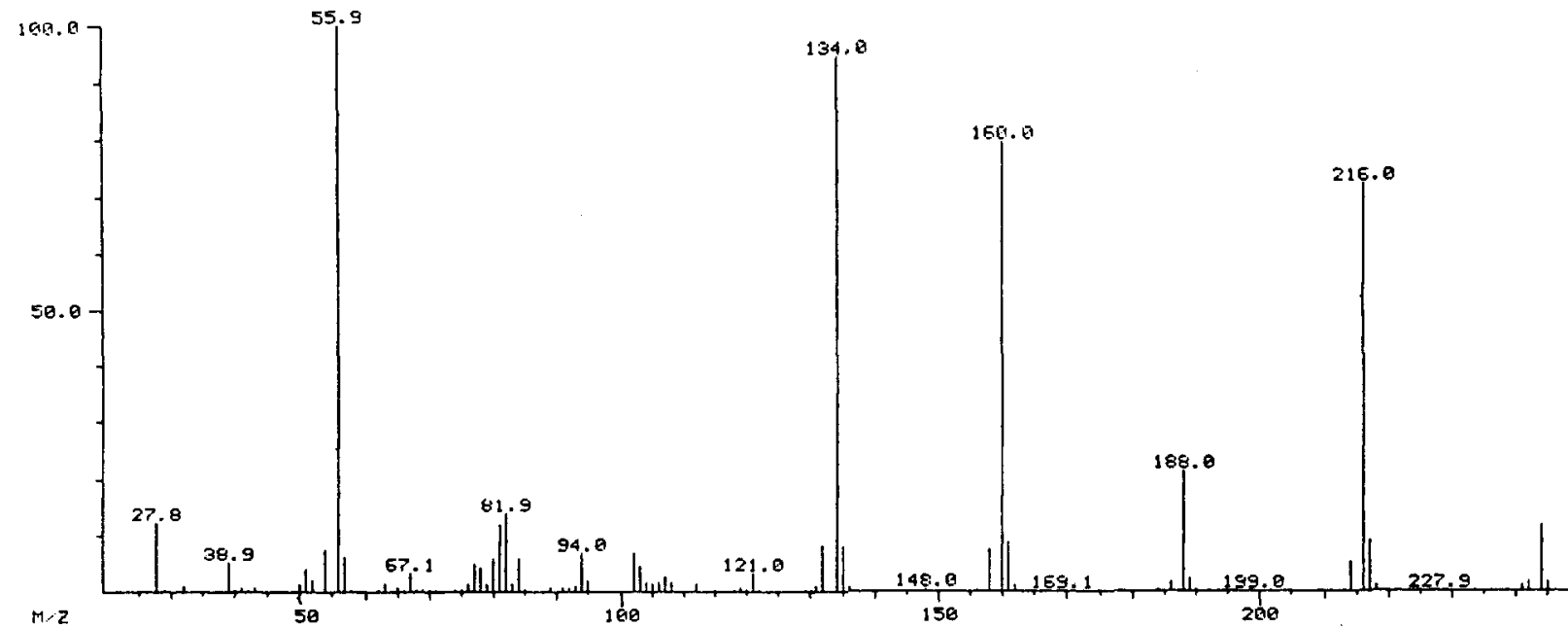

Figure 2. Mass spectrum of the pyrolysis of $(\mathrm{COT}) \mathrm{Fe}(\mathrm{CO})_{3}$ : desorbed masses $m / e \quad 20-300$ at $343 \mathrm{~K}$.

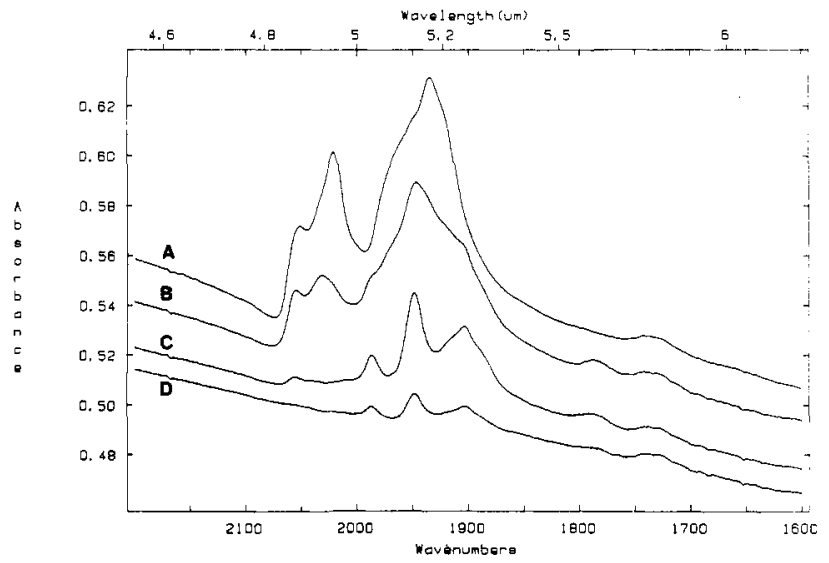

Figure 3. FTIR spectra of the thermal treatment of 1 in $\mathrm{Na}-\mathrm{Y}$ : (A) at room temperature, (B) at $349 \mathrm{~K},(\mathrm{C})$ at $355 \mathrm{~K},(\mathrm{D})$ at $360 \mathrm{~K}$

3 and zeolite sodium cannot be observed in $\mathrm{H} 6-\mathrm{Y}$ because the cations are virtually absent in this support.

Thermal Decomposition of Solid $(\mathrm{COT}) \mathrm{Fe}(\mathrm{CO})_{3}$ in $\mathrm{Na}-\mathrm{Y}$. The stability of the intrazeolite iron complexes was studied with TPD-MS techniques. Mass spectra of the thermal decomposition process of the pure unsupported compound [1] were recorded for reference purposes. It was found that upon heating the complex relatively quickly $(23 \mathrm{~K} / \mathrm{min})$, sublimation occurs at $343 \mathrm{~K}$ prior to any decomposition. The main mass fragments detected are $\mathrm{M}$ - CO (m/e 216), M - 2CO (m/e 188), M - 3CO (m/e 160), M - $3 \mathrm{CO}-\mathrm{C}_{2} \mathrm{H}_{2}(m / e$ 134), and $\mathrm{Fe}(m / e$ 56); $\mathrm{M}$ denotes (CO$\mathrm{T}) \mathrm{Fe}(\mathrm{CO})_{3}$. The mass spectrum at $343 \mathrm{~K}$ is shown in Figure 2. If the precursor [1] resides in $\mathrm{Na}-\mathrm{Y}$ zeolite (sample $\mathrm{Na}-\mathrm{Y}$ / COT), the thermal decomposition process is quite different from the unsupported complex (see Figure 3 for IR data). A decrease in intensity of the $\mathrm{CO}$ bands occurs at $328 \mathrm{~K}$ with dramatic changes beginning at about $349 \mathrm{~K}$ (Figure 3B). The bands between 1900 and $2000 \mathrm{~cm}^{-1}$ resolve into three peaks $(1986,1948$, and $1903 \mathrm{~cm}^{-1}$ ) at $355 \mathrm{~K}$ (Figure $3 \mathrm{C}$ ). These peaks are assigned to species II. All remaining carbonyl ligands are split off at 382 $\mathrm{K}$ (not shown). These processes are related to a strong $\mathrm{CO}$ peak detected in the corresponding mass spectrum with a maximum at $352 \mathrm{~K}$ (Figure 4). Simultaneously, smaller amounts of the fragments $\mathrm{C}_{8} \mathrm{H}_{8}\left(m / e\right.$ 104) and $\mathrm{C}_{6} \mathrm{H}_{6}(\mathrm{~m} / \mathrm{e}$ 78) are observed in the mass spectra. These fragments have been reported to be decomposition products of 1 in the mass spectrometer. ${ }^{13,14}$

Close inspection of the CO peak in the TPD-MS spectrum of $\mathrm{Na}-\mathrm{Y} / \mathrm{COT}$ reveals an asymmetric tail toward higher temperature. This tailing-off region is not accompanied by measurable

(13) King, R. B. Appl. Spectrosc. 1969, 23, 536

(14) Hunt, D. F.; Russell, J. W.; Torrian, R. L. J. Organomet. Chem. $1972,43,175$.

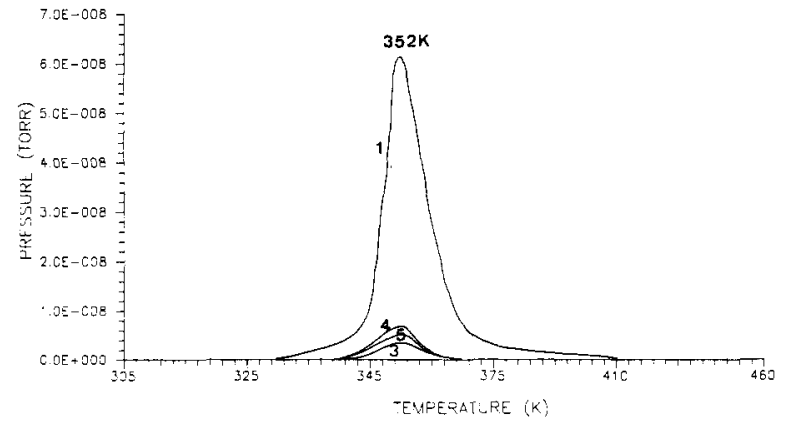

Figure 4. TPD-MS spectra corresponding to FTIR spectra of sample $\mathrm{Na}-\mathrm{Y} / \mathrm{COT}$ in Figure $3: 1, m / e$ 28; $2, m / e$ 44; $3, \mathrm{~m} / \mathrm{e} 51 ; 4, \mathrm{~m} / \mathrm{e}$ 78; $5, m / e 104$. Masses 3,4 , and 5 evolve together with mass 1 ; mass 2 is undetectable.

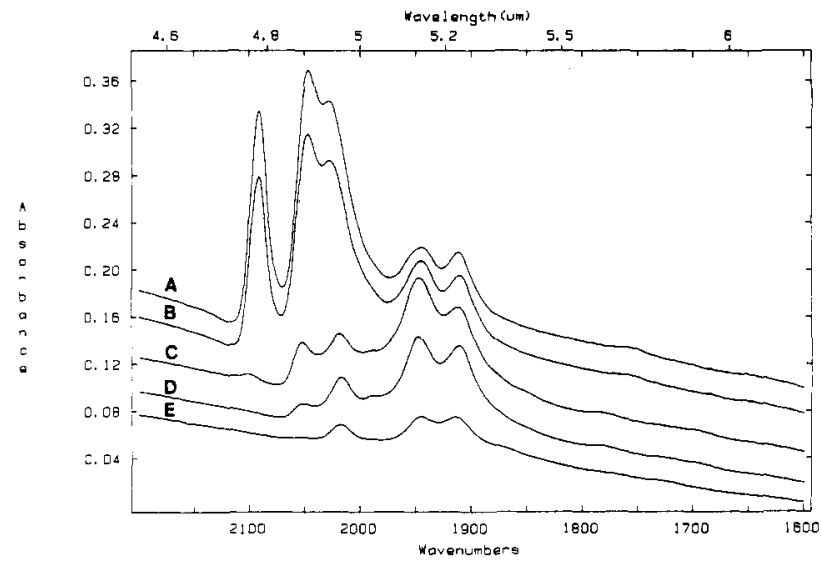

Figure 5. FTIR spectra of the thermal treatment of 1 in $\mathrm{H} 2-\mathrm{Y}$ (sample H2-Y/COT): (A) room temperature, (B) $325 \mathrm{~K}$, (C) $341 \mathrm{~K}$, (D) 349 $\mathrm{K}$, (E) $382 \mathrm{~K}$.

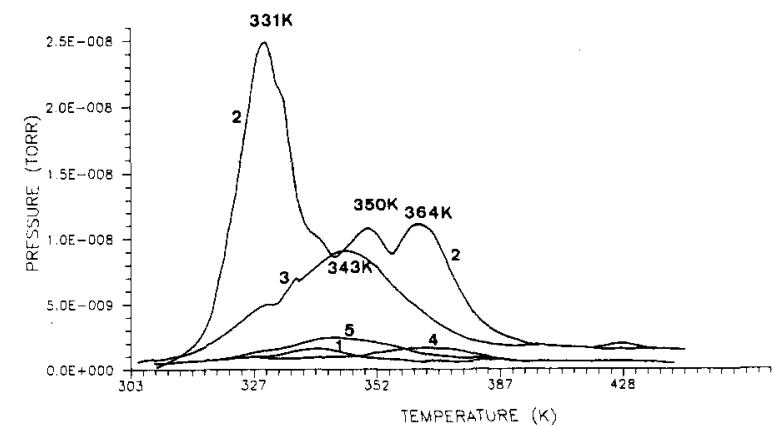

Figure 6. TPD-MS spectra of sample $\mathrm{H} 2-\mathrm{Y} / \mathrm{COT}$ corresponding to FTIR spectra in Figure $5: 1, m / e 18 ; 2, m / e 28 ; 3, m / e 42 ; 4, m / e$ 78, $5, m / e 72$. 
TABLE II: Infrared Carbonyl Frequencies of Pure and Zeolite-Loaded Iron Compounds

\begin{tabular}{llll}
\hline \multicolumn{1}{c}{ compounds } & conditions & \multicolumn{1}{c}{ CO frequencies, $\mathrm{cm}^{-1}$} & ref \\
\hline (COT) $\mathrm{Fe}(\mathrm{CO})_{3}[\mathbf{1}]$ & hexane & $2054 \mathrm{~s}, 1996 \mathrm{~s}, 1979 \mathrm{~s}$ & this work \\
$(\mathrm{COT}) \mathrm{Fe}(\mathrm{CO})_{3}[\mathbf{1}]$ & $\mathrm{KBr}$ & $2043 \mathrm{~s}, 1990 \mathrm{~s}, 1963 \mathrm{~s}$ & this work \\
$\mathbf{3}^{a}$ & $\mathrm{Cs} / \mathrm{CCl}_{4}$ & $2108 \mathrm{~s}, 2055 \mathrm{~s}$ & 8 \\
$\mathbf{4}^{a}$ & hexane & $2088 \mathrm{~s}, 2036 \mathrm{~s}, 2017 \mathrm{~s}$ & 11 \\
$\mathbf{5}^{a}$ & hexane & $2070 \mathrm{~s}, 2020 \mathrm{~s}, 2015 \mathrm{~s}$ & 11 \\
$\mathbf{6}^{a}$ & $\mathrm{Cs}_{2} / \mathrm{CCl}_{4}$ & $2025 \mathrm{~s}, 1965 \mathrm{~s}, 1920 \mathrm{~s}$ & 8 \\
$\mathrm{Fe}(\mathrm{CO})_{5}$ & gaseous & $2124 \mathrm{w}, 2127 \mathrm{w}, 2110 \mathrm{~m}, 2087 \mathrm{~m}, 2034 \mathrm{vvs,}$ & 20 \\
$\mathrm{Fe}(\mathrm{CO})_{5}$ & $\mathrm{H}-\mathrm{Y}$ & $2014 \mathrm{vvs}, 1976 \mathrm{vs}, 1935$ & 21 \\
$\mathrm{Na}-\mathrm{Y} / \mathrm{COT}$ & $\mathrm{RT}$ & $2120,2050,2020,1986,1956$ & this work \\
$\mathrm{Na}-\mathrm{Y} / \mathrm{COT}$ & $355 \mathrm{~K}$ & $2051,2021 \mathrm{~s}, 1950 \mathrm{sh}, 1935 \mathrm{~s}$ & this work \\
$\mathrm{H} 2-\mathrm{Y} / \mathrm{COT}$ & $\mathrm{RT}$ & $1986,1948,1903$ & this work \\
$\mathrm{H} 2-\mathrm{Y} / \mathrm{COT}$ & $349 \mathrm{~K}$ & $2092 \mathrm{~s}, 2047 \mathrm{~s}, 2029 \mathrm{sh}, 1945,1912$ & this work \\
$\mathrm{H} 6-\mathrm{Y} / \mathrm{COT}$ & $\mathrm{RT}$ & $2050,2017,1989,1948,1911$ & this work \\
$\mathrm{H}-\mathrm{Y} / \mathrm{COT}-\mathrm{R}$ & $\mathrm{RT}$ & $2101 \mathrm{~s}, 2058 \mathrm{~s}, 2028 \mathrm{sh}$ & this work \\
$\mathrm{H}-\mathrm{Y} / \mathrm{COT}-373$ & $373 \mathrm{~K}$ & $2101 \mathrm{~s}, 2060 \mathrm{~s}, 1957 \mathrm{w}, 1919 \mathrm{w}$ & this work
\end{tabular}

${ }^{a}$ Notation for protonation products as shown in Scheme I.

amounts of $\mathrm{C}_{6} \mathrm{H}_{6}$ or $\mathrm{C}_{8} \mathrm{H}_{8}$, but it is correlated to the decrease of the second compound, II, which is indicated by a set of three peaks at 1986,1948 , and $1903 \mathrm{~cm}^{-1}$ in the FTIR data. It should be noted that no traces of $\mathrm{Fe}(m / e 56)$ are found. This shows that 1 does not sublime as an intact molecule from the zeolite cages.

Thermal Decomposition of $(\mathrm{COT}) \mathrm{Fe}(\mathrm{CO})_{3}$ in $\mathrm{H2}-\mathrm{Y}$. The thermal stability of 1 in the partially proton exchanged zeolite (sample H2-Y/COT) was monitored by FTIR (Figure 5) and TPD-MS (Figure 6). The FTIR data indicate that the dominant compound, which was assigned to the bicyclic intrazeolite complex [3], is decomposed at $349 \mathrm{~K}$ (Figure 5D). A second complex with CO stretching frequencies at 1989,1948 , and $1911 \mathrm{~cm}^{-1}$ is comparable in band position and thermal stability to species II found in $\mathrm{Na}-\mathrm{Y} / \mathrm{COT}$. A third, unknown compound with a band shifting from 2029 to $2017 \mathrm{~cm}^{-1}$ during heating is of intermediate stability. Three maxima are observed in the $\mathrm{CO}$ mass trace of the corresponding TPD-MS spectra in Figure 6. The TPD-MS spectra reflect the successive decomposition of the different intrazeolite carbonyl compounds. The first predominant $\mathrm{CO}$ peak $(\mathrm{m} / \mathrm{e} 28)$ with a maximum at $331 \mathrm{~K}$ clearly correlates to the decomposition of intrazeolite compound 3 , while the small $\mathrm{CO}$ peak with a maximum at $350 \mathrm{~K}$ is related to the unidentified species with a frequency at $2017 \mathrm{~cm}^{-1}$ in the IR. The CO peak at $364 \mathrm{~K}$ appears in the same temperature range as the tail found in the CO mass peak of sample $\mathrm{Na}-\mathrm{Y}$, supporting the assumption that both are due to the decomposition of species II. In contrast to sample $\mathrm{Na}-\mathrm{Y} / \mathrm{COT}$, the fragments $\mathrm{C}_{8} \mathrm{H}_{8}(m / e) 104$, not shown) and $\mathrm{C}_{6} \mathrm{H}_{6}$ $(m / e$ 78) are found in only very small amounts. This is consistent with the absence of weakly interacting 1 in this sample (species 1). Additional mass traces of $m / e 42$ and $m / e 72$ result from the residual hexane used in the IR-sample preparation.

Thermal Decomposition of $(\mathrm{COT}) \mathrm{Fe}(\mathrm{CO})_{3}$ in $\mathrm{H6}-\mathrm{Y}$. If the precursor [1] is loaded into highly acidic zeolite (sample H6Y/COT, Figure 7), the bicyclic homotropylium complex [3] is formed in a remarkably clean reaction. In addition to the corresponding bands at 2101 and $2058 \mathrm{~cm}^{-1}$, only a small shoulder at $2028 \mathrm{~cm}^{-1}$ is observed which could indicate a minor second component or effects of distorted symmetry. Upon heating the sample, the $\mathrm{CO}$ bands start decreasing at $328 \mathrm{~K}$ and have almost disappeared at $345 \mathrm{~K}$. The TPD-MS experiments show the evolution of the $\mathrm{CO}$ fragment with a single maximum at $338 \mathrm{~K}$ which corresponds to the IR results (Figure 8). Other mass fragments shown in Figure 8 are related to residual hexane, which was used for the sample preparation. A strong increase of water desorption (mass 18 ) at $439 \mathrm{~K}$ could indicate beginning dehydroxylation of the zeolite framework caused by the high level of acidity present in this sample.

Additional Experiments. All samples discussed above appear to be relatively stable against exposure to oxygen or air. No change of intensities in the characteristic $\mathrm{CO}$ peaks was found upon exposing the zeolite wafers to air. Minor shifts of band positions are reversible when the samples were subsequently evacuated. After thermal treatment at $460 \mathrm{~K}$, the samples were

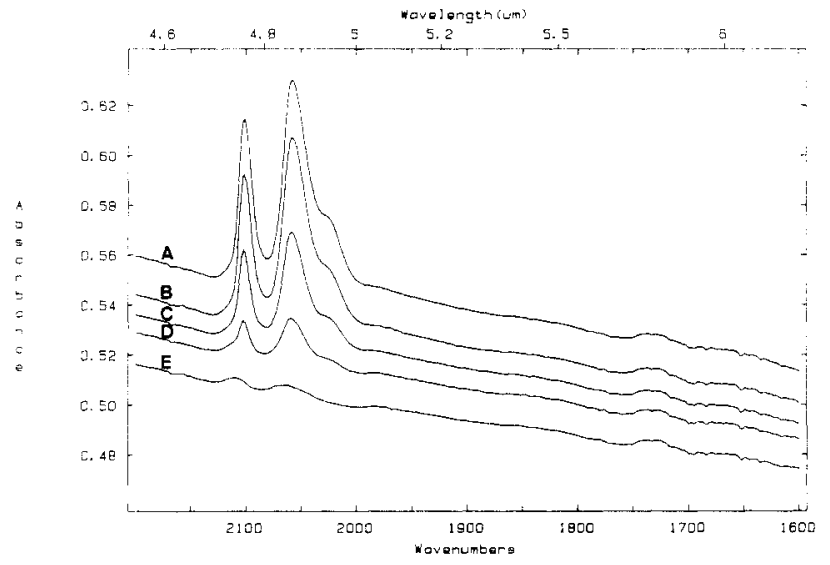

Figure 7. FTIR spectra of the thermal treatment of 1 in H6-Y (sample H6-Y/COT): (A) room temperature, (B) $328 \mathrm{~K}$, (C) $336 \mathrm{~K}$, (D) 341 $\mathrm{K}$, (E) $345 \mathrm{~K}$.

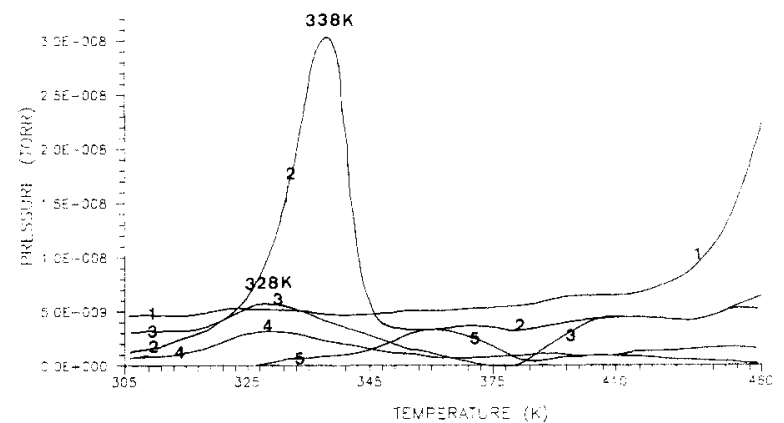

Figure 8. TPD-MS spectra of sample $\mathrm{H} 6-\mathrm{Y} / \mathrm{COT}$ corresponding to FTIR spectra in Figure 7: $1, m / e$ 18; $2, m / e$ 28; $3, m / e ~ 41 ; 4, m / e$ 56; $5, m / e 91$

exposed to 20 Torr of carbon monoxide at room temperature. Only gaseous $\mathrm{CO}$ was detected in the cell which was completely removable upon evacuation. Thus, no new complexes were formed as expected for the coordinatively saturated ligand spheres of the proposed zeolite-anchored iron fragments (see Discussion).

Thermal Decomposition and EXAFS Studies of (COT)Fe(C. $O)_{3}$ in $H-Y$. EXAFS studies and FTIR-TPD-MS experiments were performed with sample $\mathrm{H}-\mathrm{Y} / \mathrm{COT}$. As indicated by FTIR data, this sample contains complex $\mathbf{3}$ as the only reaction product upon loading with 1 . The masses of desorbing gases found in the thermodesorption experiments are comparable to those found with H6-Y/COT. Carbon monoxide appears as the only volatile decomposition product. An interesting difference of sample $\mathrm{H}-\mathrm{Y} / \mathrm{COT}$ compared to $\mathrm{H} 6-\mathrm{Y} / \mathrm{COT}$ is the higher stability of 3 in the $\mathrm{H}-\mathrm{Y}$ support: small amounts of $\mathrm{CO}$ desorbing from $\mathrm{H}-\mathrm{Y} / \mathrm{COT}$ were still detected at $385 \mathrm{~K}$ when a linear heating program was applied 

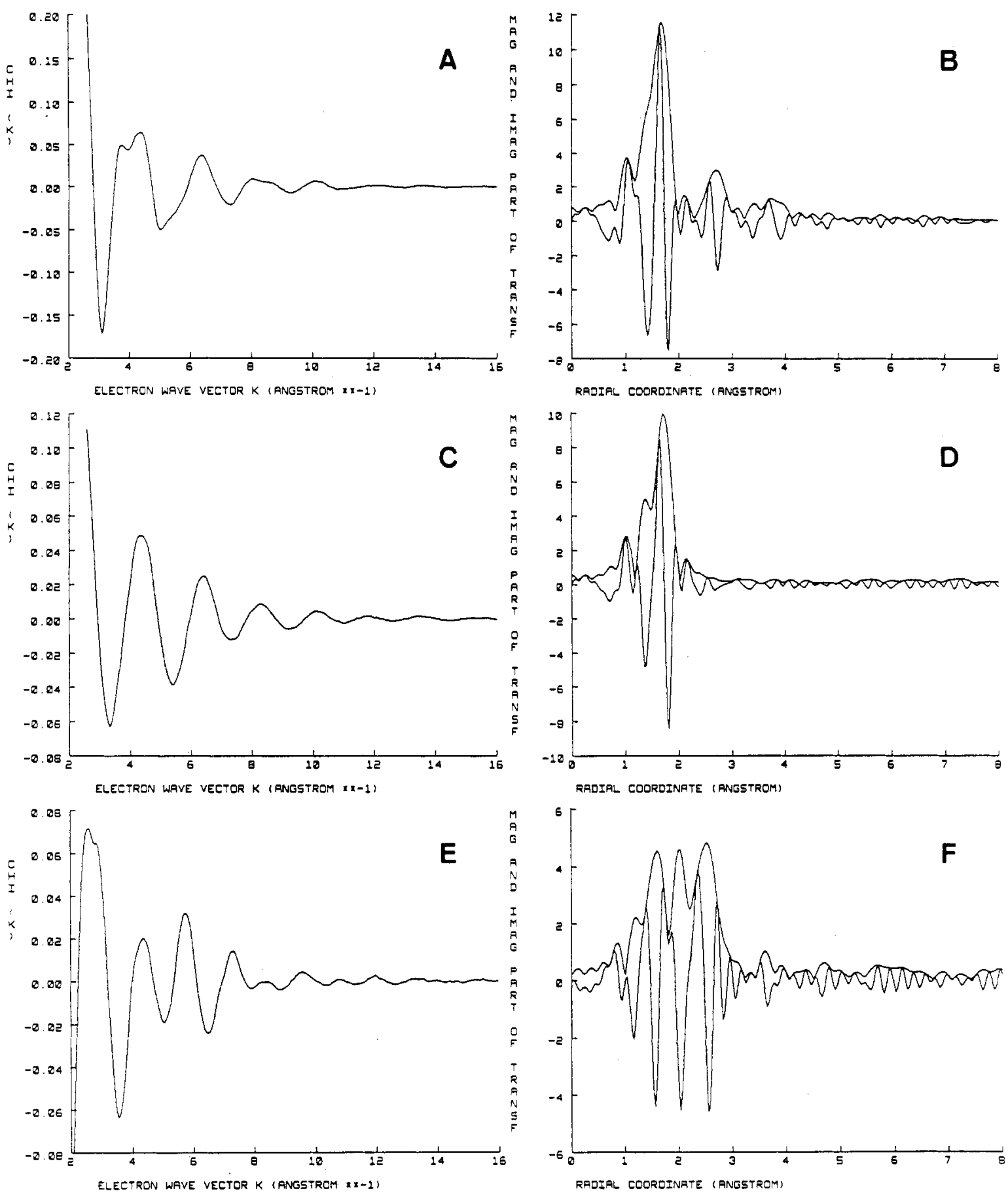

Figure 9. Normalized EXAFS data (A, C, E) and corresponding $k^{3}$-weighted FT (B, D, F; magnitude and imaginary part) of reference samples: (A and B) $\mathrm{Fe}^{\mathrm{III}}(\mathrm{acac})_{3}$; (C and D) ferrocene; (E and $\left.\mathrm{F}\right) \mathrm{C}_{3} \mathrm{H}_{5} \mathrm{Fe}(\mathrm{CO})_{3} \mathrm{Cl}$.

EXAFS measurements were performed on a sample loaded with (COT) $\mathrm{Fe}(\mathrm{CO})_{3}$ at room temperature (sample $\mathrm{H}-\mathrm{Y} / \mathrm{COT}-\mathrm{R}$ ), and after a thermal treatment under vacuum with $1 \mathrm{~K} / \mathrm{min}$ up to 373 $\mathrm{K}$, and heating for $10 \mathrm{~h}$ (sample HYT/COT-373). IR spectra of $\mathrm{H}-\mathrm{Y} / \mathrm{COT}-373$ show that complex 3 has lost about $70 \%$ of the carbonyl ligands. The EXAFS analysis of these samples was accomplished by using the following reference compounds: $\mathrm{Fe}^{\mathrm{III}}$ (acac) ${ }_{3}$ for the $\mathrm{Fe}-\mathrm{O}$ atom pair, ferrocene for the $\mathrm{Fe}-\mathrm{C}$ contribution, and $\mathrm{FeC}_{3} \mathrm{H}_{5}(\mathrm{CO})_{3} \mathrm{Cl}$ for $\mathrm{Fe}-\mathrm{CO}$. Crystallographic data of the reference compounds and Fourier transform ranges used in the data analysis are listed in Table III. The corresponding normalized EXAFS functions and their Fourier transformations (magnitude and imaginary part) are shown in Figure 9. The Fourier transformations are not corrected for phase shifts, and peak positions appear about $0.3-0.5 \AA$ shorter than actual values.

Sample $H-Y / C O T-R$. Parts A and B of Figure 10 show the normalized EXAFS function and the corresponding $k^{3}$-weighted
TABLE III: Fourier Transform Ranges, Interatomic Distances, $R$, and Coordination Numbers, $N$, of Reference Compounds

\begin{tabular}{|c|c|c|c|c|c|c|}
\hline \multirow[b]{2}{*}{ ref compd } & \multirow[b]{2}{*}{ scatterer } & \multicolumn{2}{|c|}{$\begin{array}{c}\text { Fourier transform } \\
\text { ranges }\end{array}$} & \multicolumn{3}{|c|}{ crystallogr data } \\
\hline & & $k^{3} / \AA^{-1}$ & $R / \AA$ & $R / \AA$ & $N$ & $\overline{\text { ref }}$ \\
\hline $\begin{array}{l}\mathrm{Fe}^{\mathrm{HI}}(\mathrm{acac})_{3} \\
\mathrm{FeC}_{2} \\
\mathrm{FeC}_{3} \mathrm{H}_{5}(\mathrm{CO})_{3} \mathrm{Cl}\end{array}$ & $\begin{array}{l}\mathrm{Fe}-\mathrm{O} \\
\mathrm{Fe}-\mathrm{C} \\
\mathrm{Fe}-\mathrm{CO}\end{array}$ & $\begin{array}{l}3.5-15.8 \\
3.8-15.8 \\
3.2-15.8\end{array}$ & $\begin{array}{l}1.2-2.3 \\
1.2-2.6 \\
2.2-3.0\end{array}$ & $\begin{array}{l}1.992 \\
2.033 \\
2.928^{a}\end{array}$ & $\begin{array}{r}6 \\
10 \\
3\end{array}$ & $\begin{array}{l}22 \\
23 \\
24\end{array}$ \\
\hline
\end{tabular}

${ }^{a}$ Mean value from literature data for $\mathrm{FeC}_{3} \mathrm{H}_{5}(\mathrm{CO})_{3} \mathrm{Br}$.

Fourier transformation (magnitude and imaginary part) of sample $\mathrm{H}-\mathrm{Y} / \mathrm{COT}-\mathrm{R}$. Two fairly isolated shells are observed in the Fourier transformation which can be attributed to an iron-carbon sphere due to the olefin ligands convoluted with the carbon atoms of the $\mathrm{CO}$ ligands and an $\mathrm{Fe}-\mathrm{CO}$ oxygen sphere due to the carbonyls. The carbonyls, with their close-to-linear $\mathrm{Fe}-\mathrm{C}-\mathrm{O}$ 

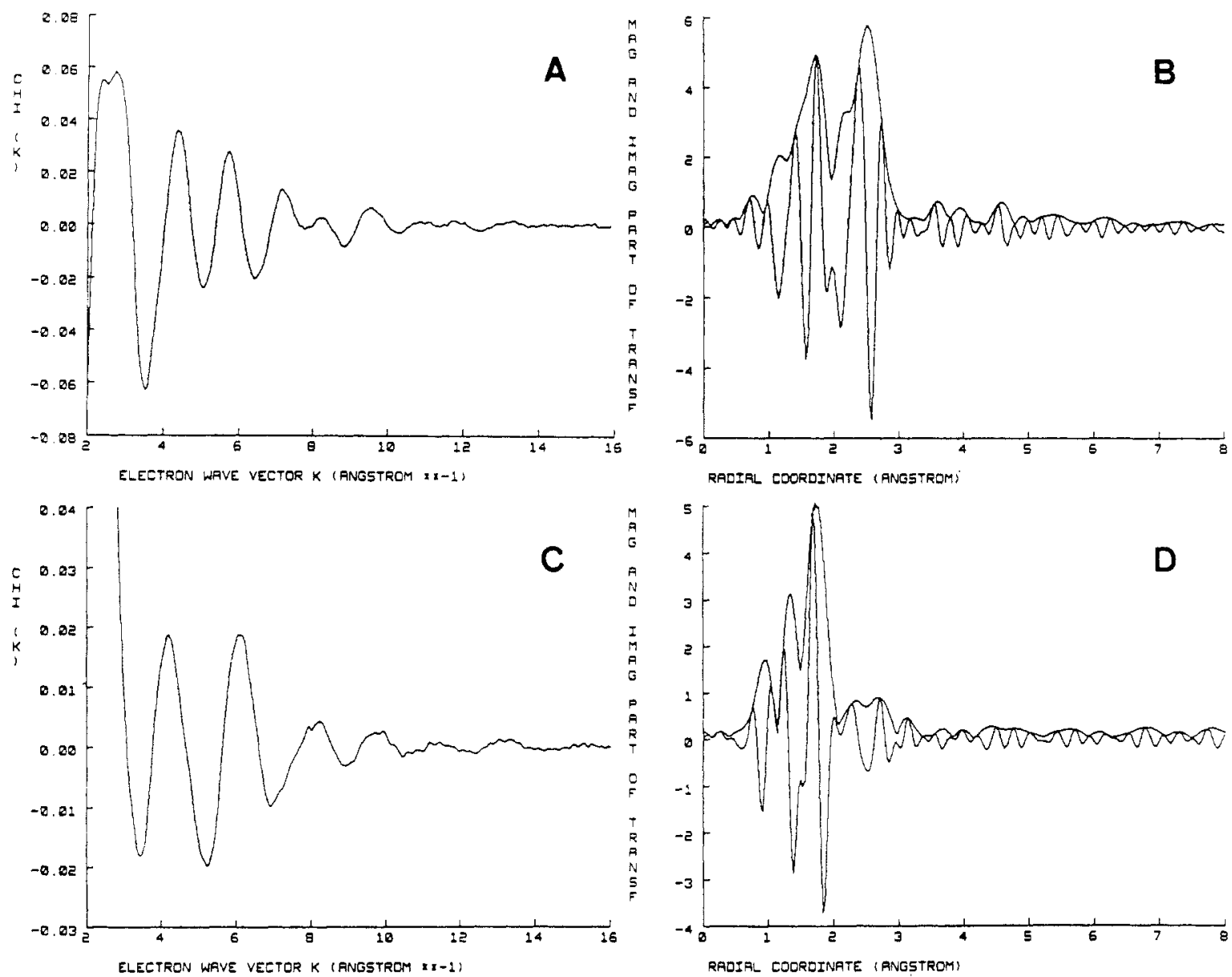

Figure 10. Normalized EXAFS data (A, C) and corresponding $k^{3}$-weighted FT (B, D; magnitude and imaginary part) of $(\mathrm{COT}) \mathrm{Fe}(\mathrm{CO})_{3}$ loaded zeolite samples $\mathrm{H}-\mathrm{Y} / \mathrm{COT}-\mathrm{R}(\mathrm{A}, \mathrm{B})$ and $\mathrm{H}-\mathrm{Y} / \mathrm{COT}-373$ (C, D).

arrangement, show enhanced peak intensities due to multiple scattering.

Fitting of these EXAFS data was performed in three successive steps to minimize the number of fitting variables and hence obtain most reliable results: separate fits were carried out on the first shell (back-transformation range 1.2-2.0 $\AA$ ) and the second shell (back-transformation range $2.2-2.9 \AA$ ). All fit results were then combined and used as starting parameters in a fit over the whole data range $(1.2-2.9 \AA)$. EXAFS data of both isolated shells and the total EXAFS function are compared to calculated functions in Figure $11 \mathrm{~A}-\mathrm{C}$. The quality of the fits was judged not only based upon this comparison but also by examination of the Fourier transformation of the calculated contributions (Figure 11D). Figure 11 demonstrates the excellent agreement between experimental and calculated data. The fit results are listed in Table IV.

There are three different $\mathrm{Fe}-\mathrm{C}$ contributions convoluted in the first shell of sample H-Y/COT-R. Due to the lack of structural data for complex 3, our EXAFS results are compared with crystallographic data of $\mathbf{1}$, included in parentheses in Table IV. Thus, the short $\mathrm{Fe}-\mathrm{C}$ distance of $1.82 \AA$ is attributed to the $\mathrm{Fe}-\mathrm{CO}$ atom pair. This value is characteristic of iron carbonyl compounds and is very close to that of $(\mathrm{COT}) \mathrm{Fe}(\mathrm{CO})_{3}(1.80 \AA)$. The $\mathrm{Fe}-\mathrm{CO}$ bond length compares also very well. The corresponding coordination numbers of $3.4(-\mathrm{C})$ and $3.7(-\mathrm{O})$ point most likely toward the existence of three carbonyl ligands coordinated to iron.

Two additional $\mathrm{Fe}-\mathrm{C}$ contributions are found at 2.13 and 2.30 $\AA$. In the pure precursor, the COT ligand is bonded in $\eta^{4} \mathrm{co}-$ ordination to iron while the remaining four carbons are bent away from the metal center. The mean value for the iron-diene bond length in $(\mathrm{COT}) \mathrm{Fe}(\mathrm{CO})_{3}$ was reported to be $2.11 \AA .{ }^{15}$ This is close to the shorter value found with EXAFS for sample $\mathrm{H}-$ $Y / C O T-R$, and it is therefore assigned to the distance between
TABLE IV: Bond Distances, $R$, Coordination Numbers, $\boldsymbol{N}$, Debye-Waller Deviations, $\sigma^{2}$, and Deviations from the Inner Potential, $E$, of Iron Complexes in Zeolite $Y$ as derived from EXAFS Data ${ }^{a}$

\begin{tabular}{cllllr}
\hline sample & scatter pair & \multicolumn{1}{c}{$R / \AA^{b}$} & \multicolumn{1}{c}{$N^{b}$} & \multicolumn{1}{c}{$\Delta \sigma^{2} / \AA^{2}$} & $\Delta E$ \\
\hline H-Y/COT-R & Fe-CO & $1.82(1.80)$ & $3.4(3)$ & 0.0004 & 0 \\
& Fe-C & $2.13(2.11)$ & $5.6(4)$ & 0.001 & 0 \\
& Fe-C & 2.30 & 2.4 & 0.0006 & 0 \\
H-Y/COT-373 & Fe-CO & $2.94(2.92)$ & $3.7(3)$ & 0.0004 & 0 \\
& Fe-CO & 1.84 & 0.7 & -0.0007 & -1 \\
& re-O & 2.16 & 1.9 & -0.0004 & -3 \\
& Fe-C & 2.07 & 7.1 & -0.00009 & -3
\end{tabular}

${ }^{a}$ Accuracy of $N$ and $\Delta \sigma^{2}, \pm 20-30 \% ;$ of $\mathrm{R}, \pm 1-2 \%$ ${ }^{b}$ Crystallographic data for (COT) $\mathrm{Fe}(\mathrm{CO}){ }_{3}{ }^{16}$ are listed in parentheses.

the iron and bond-forming carbons (most likely five carbons in complex 3). We attribute the second distance of $2.30 \AA$ to the ring carbons bent away from the iron. IR spectra of the sample show two strong carbonyl stretching bands at 2060 and $2101 \mathrm{~cm}^{-1}$ which very closely resemble those found in sample H6Y/COT. These bands are assigned to the homotropylium iron tricarbonyl cation [3]. In summary, the EXAFS data of sample $\mathrm{H}-\mathrm{Y} /$ COT- $R$ are consistent with an iron tricarbonyl complex ligated by the bicyclic homotropylium ring, with five carbons close to the iron in an $\eta^{5}$ conformation $(R=2.13 \AA)$, and an iron-carbon interaction with two carbons of the cyclopropyl part $(R=2.30$ $\AA$ ).

Sample $H-Y / C O T-373$. If the Fourier transformations of sample H-Y/COT-373 (Figure 10D) are compared with those of sample H-Y/COT-R (Figure 10B), drastic changes are observed in the second shell. The carbonyl (oxygen) contribution in $\mathrm{H}-\mathrm{Y} / \mathrm{COT}-373$ is almost vanished after a heating period of $10 \mathrm{~h}$ under vacuum, while the first shell remains similar in magnitude. The IR spectra of this sample show the corresponding reduction of the carbonyl bands to about one-third of their original 

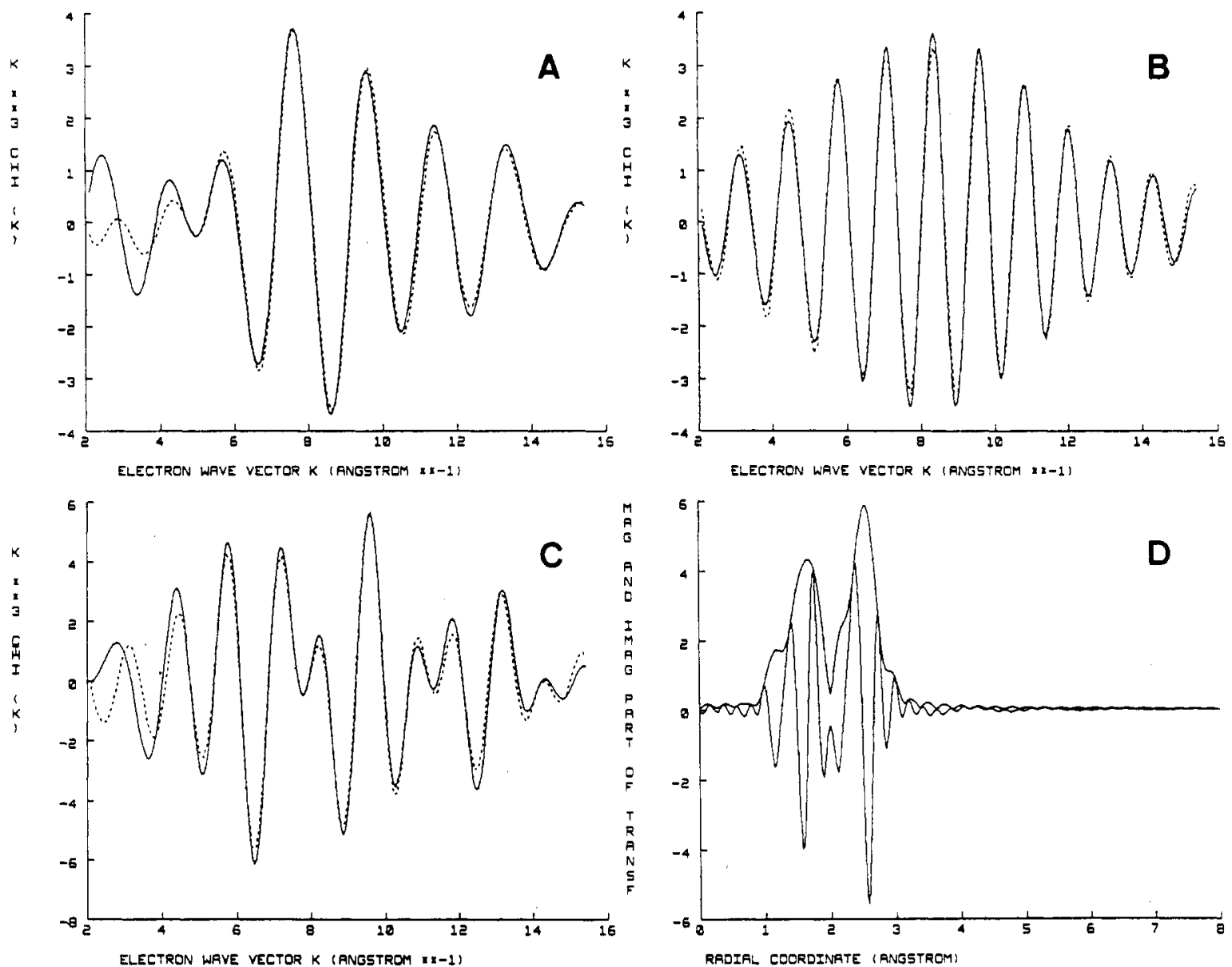

Figure 11. EXAFS data and fit results of sample H-Y/COT-R. (A-C) $k^{3}$-weighted EXAFS modulations of the first shell (A), second shell (B), and total file (C). Solid lines, experimental data; broken lines, calculated data. (D) shows the Fourier transformation (magnitude and imaginary part) on $(\mathrm{C})$.
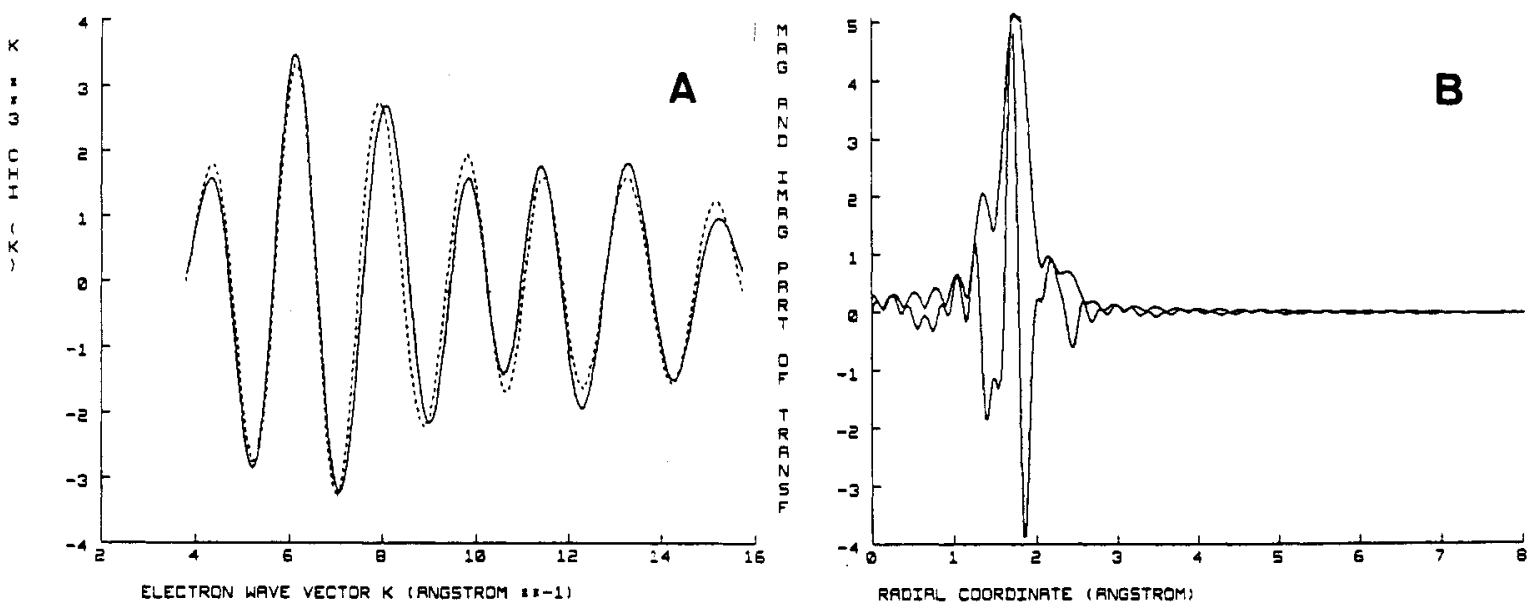

Figure 12. EXAFS data and fit results of sample H-Y/COT-373. (A) $k^{3}$-weighted experimental (solid line) and calculated (broken line) EXAFS modulations. (B) Fourier transformation (magnitude and imaginary part) of the calculated EXAFS in (b).

intensity, and they are slightly shifted to higher wavenumbers at 2063 and $2110 \mathrm{~cm}^{-1}$. Correspondingly, the best fit of this sample contains a small contribution $(N=0.7)$ of an Fe-C coordination $(R=1.84 \AA)$, similar to that found in sample $\mathrm{H}-\mathrm{Y} / \mathrm{COT}-\mathrm{R}$, which is assigned to the carbonyl carbon. The main contribution consists of a second $\mathrm{Fe}-\mathrm{C}$ scatter pair $(N=7.1)$, with a bond length reduced to $2.07 \AA$ from $2.13 \AA$ in $\mathrm{H}-\mathrm{Y} / \mathrm{COT}$-R (Figure 12). The effect of heating on the $\mathrm{Fe}-\mathrm{C}$ coordination number may be due to a rearrangement of the olefinic ligand. The EXAFS data positively show the retainment of the organic ligand at the metal center, even though the limited precision of EXAFS-derived coordination numbers does not allow determination of the precise structure of the intrazeolite complex.
In contrast to sample $\mathrm{H}-\mathrm{Y} / \mathrm{COT} \cdot \mathrm{R}$, the heated sample shows a new coordination to oxygen atoms at $2.16 \AA(N=1.9)$ which indicates a close interaction of the remaining fragment with the intrazeolite oxygen surface. It is difficult to distinguish carbon and oxygen backscattering atoms by EXAFS spectroscopy. The analysis of the first coordination sphere of this sample was aided by analogies with similar $\mathrm{Fe} /$ zeolite systems. A fit of this sphere based exclusively on carbon resulted in chemically unreasonable high coordination numbers. However, if an additional oxygen sphere was included, the fit converged to the above results. Very similar coordination values were obtained in our study of intrazeolite cyclopentadienyliron dicarbonyl dimer after vacuum treatment at $473 \mathrm{~K}(\mathrm{Fe}-\mathrm{Cp}: N=5.4, R=2.07 \AA ; \mathrm{Fe}-\mathrm{O}: N$ 
$=1.9, R=2.16 \AA) .11$ In that study, the assignments of neighbor shells to carbon and oxygen coordination were based upon bond distances and coordination numbers derived from the EXAFS data of iron ions in zeolite $\mathrm{Y}$ cation positions, ferrocene, and zeoliteanchored $\mathrm{CpFe}^{+}$fragments. It appears that the unsaturated ligands move closer to the iron center upon anchoring to the support. It was suggested that the "half-sandwich" $\mathrm{Fe}-\mathrm{Cp}$ be coordinated to zeolite oxygens in SIII positions in the supercage A small peak at about $2.8 \AA$ in sample $\mathrm{H}-\mathrm{Y} / \mathrm{COT}-373$ (Figure 10D), characteristic for an $\mathrm{Fe}-\mathrm{O}-\mathrm{Si} / \mathrm{Al}$ interaction, together with the $\mathrm{Fe}-\mathrm{O}$ contribution suggests the presence of a comparable, zeolite-anchored $(\mathrm{ZO})_{2}-\mathrm{Fe}-\mathrm{C}_{8} \mathrm{H}_{9}$ fragment.

\section{Discussion and Summary}

As shown in this study, the chemistry of (COT) $\mathrm{Fe}(\mathrm{CO})_{3}[\mathbf{1}]$ in the cage system of zeolite $\mathrm{Y}$ is determined by the concentration of framework protons present. The IR spectrum of complex 1 in the $\mathrm{Na}-\mathrm{Y}$ host is explained with the presence of two intrazeolite forms of 1 . Both are believed to originate from symmetry changes of the precursor introduced into the confinement of the zeolite cavities. A majority of the complex molecules is shielded from interactions with the sodium cations by other complexes. This fraction is expected to have moderately perturbed IR spectra as observed with solid 1 in $\mathrm{KBr}$. A closer contact to the zeolite "walls", however, leads to a stronger interaction between the $\mathrm{CO}$ ligands and the $\mathrm{Na}^{+}$cations such as $\mathrm{Na}^{+} \ldots \mathrm{OC}-\mathrm{Fe}$ which resembles contact ion-pair interactions of carbonyl complexes with alkalimetal cations in solution. ${ }^{16}$ The effect of this $\mathrm{Na}-\mathrm{OC}$ interaction is a lower symmetry of the complex, resulting in split peaks and lower frequencies. It is assumed that species II, which evolves more clearly from the asymmetric peak at $1935 \mathrm{~cm}^{-1}$ upon decomposition of the less perturbed complex 1 (species I) at higher temperatures, is due to the $\mathrm{Na}^{+} \ldots \mathrm{OC}-\mathrm{Fe}$ interaction.

Similar effects of lowered symmetry and band splitting were found in an earlier study of nickel carbonyl complexes in different zeolite supports. ${ }^{17}$ The zeolite sodium ions were identified as the reason for a dramatic splitting of the degenerate $\mathrm{CO}$ stretching modes of $\mathrm{Ni}(\mathrm{CO})_{4}$ in $\mathrm{Na}-\mathrm{Y}$ zeolites. Dealuminated zeolites, containing no sodium ions, did not show this effect. EXAFS data demonstrated that the local structure of the $\mathrm{Ni}$ carbonyl complex was nearly identical in both zeolite environments. Intrazeolite $\mathrm{Ni}(\mathrm{CO})_{3} \mathrm{~L}$ complexes showed strong surface interactions at low loading levels, causing splitting of the $\mathrm{E}$ mode, while at high loading the IR bands were only broadened and shifted to lower frequencies.

Other alternative assignments for species Il are less probable. The observed band positions at 1986, 1948, and 1903 are too low for cationic and too high for anionic iron carbonyl species because these compounds typically have bands with frequencies above 2100 $\mathrm{cm}^{-1}$ and below $1800 \mathrm{~cm}^{-1}$, respectively. The observed band positions of species II also exclude the presence of compounds with bridged carbonyl ligands such as $\mathrm{Fe}_{2}(\mathrm{CO})_{9}$ or $\mathrm{Fe}_{3}(\mathrm{CO})_{12}$. $\mathrm{Fe}(\mathrm{CO})_{5}$ is excluded, too, because it was observed to have five bands at different wavenumbers in a zeolite $\mathrm{H}-\mathrm{Y}$ environment (see Table I). In summary, all evidence supports the assignment of species II to a distorted, neutral (COT) $\mathrm{Fe}(\mathrm{CO})_{3}$ complex. If the IR spectra of partially degassed sample $\mathrm{Na}-\mathrm{Y} / \mathrm{COT}$ (Figure 3C) and $\mathrm{H} 2-\mathrm{Y} / \mathrm{COT}$ (Figure $5 \mathrm{C}$ ) are compared, the striking similarity of features between 1900 and $2000 \mathrm{~cm}^{-1}$ suggests that the distorted complex II is present in both cases. In the latter sample part of the original complex 1 has reacted with the acid groups to form the homotropylium complex [3], leaving the unreacted fraction exposed to an intimate contact with the sodium ions to form species II. Since complex 3 shows $\mathrm{CO}$ bands at higher frequencies, the remaining fraction of the disturbed complex $\mathrm{Na}^{+} \ldots \mathrm{OC}$ (CO) ${ }_{2}$ FeCOT in $\mathrm{H} 2-\mathrm{Y} / \mathrm{COT}$ (species II) is already observed at room temperature as shown in Figure $5 \mathrm{~A}$. Finally, the absence

(15) Dickens, B.; Lipscomb, W. N. J. Chem. Phys. 1962, 37, 2084

(16) Darensbourg, M. Y. Barros, H. C. Inorg. Chem 1979, 18, 3286

(17) Bein, T.: McLain, S.; Corbin, D. R.; Farlee, R. D.; Moller, K.; Stucky, G. D.; Woolery, G.; Sayers, D. J. Am. Chem. Soc. 1988, 110, 1801. of sodium ions and the high level of protons in sample H6-Y/COT result in the exclusive formation of homotropylium iron tricarbonyl [3].

The distribution of intrazeolite reaction products of (COT)$\mathrm{Fe}(\mathrm{CO})_{3}$ can therefore be summarized as follows:

$\mathrm{Na}-\mathrm{Y} / \mathrm{COT}:(\mathrm{COT}) \mathrm{Fe}(\mathrm{CO})_{3}+\mathrm{Na}^{+} \ldots \mathrm{OC}(\mathrm{CO})_{2} \mathrm{FeCOT}$

$\mathrm{H} 2-\mathrm{Y} / \mathrm{COT}: \mathrm{Na}^{+} \ldots \mathrm{OC}(\mathrm{CO})_{2} \mathrm{FeCOT}+\left[\mathrm{C}_{8} \mathrm{H}_{9} \mathrm{Fe}(\mathrm{CO})_{3}\right]^{+}$

$\mathrm{H} 6-\mathrm{Y} / \mathrm{H}-\mathrm{Y} / \mathrm{COT}: \quad\left[\mathrm{C}_{8} \mathrm{H}_{9} \mathrm{Fe}(\mathrm{CO})_{3}\right]^{+}$

It could be shown in this study that a chemical reaction of the zeolite support with the occluded complex occurs only in the presence of acidic groups, resembling the reaction path found in homogeneous medium with noncoordinating acids. The combined results from the EXAFS studies and in situ FTIR spectroscopy show the intrazeolite formation of bicyclo[5.1.0]octadienyliron tricarbonyl cation [3]. The solid $\mathrm{BF}_{4}^{-}$salt of 3 was found to be stable up to $453 \mathrm{~K}^{18}$ In $\mathrm{H} 2-\mathrm{Y}$ and $\mathrm{H} 6-\mathrm{Y}$ hosts the liberation of the CO ligands is completed at about $349 \mathrm{~K}$, whereas in the $\mathrm{H}-\mathrm{Y}$ host the complex is still partially intact at $385 \mathrm{~K}$. This difference may be related to the smaller amount of bridged hydroxyls present in the thermally stabilized support $\mathrm{H}-\mathrm{Y}$. The TPD-MS experiments did not show any significant fragments related to a loss of the $\mathrm{C}_{8} \mathrm{H}_{9}$ ligand or the desorption of any other iron-containing fragment. Therefore, these constituents have to be trapped in the zeolite cage system of the acid supports. The EXAFS data discussed above show indeed that the organic ligands are retained at the intrazeolite Fe metal center. In accordance with the other spectroscopic evidence, the thermal product can be described as a $\left[\mathrm{FeC}_{8} \mathrm{H}_{9}\right]^{+}$fragment which is coordinated to two zeolite oxygens in the large faujasite supercage $(\mathrm{OZ}$ is zeolite oxygen):

$\mathrm{H}-\mathrm{Y} / \mathrm{COT}-373$ :

$$
\left[\mathrm{C}_{8} \mathrm{H}_{9} \mathrm{Fe}(\mathrm{CO})_{3}\right]^{+} \bullet\left[(\mathrm{OZ})_{2}\right]^{-} \stackrel{373 \mathrm{~K}}{\longrightarrow} \mathrm{C}_{8} \mathrm{H}_{9} \mathrm{Fe}-(\mathrm{OZ})_{2}+3 \mathrm{CO}
$$

SIII positions in the supercage of the zeolite framework offer coordination sites with two bridging oxygen atoms available. Considering the molecular dimension of the starting complex [1], the $12-\AA$ supercage is the only cavity which can be occupied by the complex upon adsorption. After bond cleavage of the carbonyl ligands, the zeolite oxygens of the four-rings of the supercage SIII positions fill the coordination sphere of the remaining organo-iron fragment.

A comparable reaction that anchors a $[\mathrm{CpFe}]^{+}$fragment into zeolite cages was found upon thermal decomposition of $[\mathrm{CpFe}$ $\left.(\mathrm{CO})_{2}\right]_{2}$ in acid zeolite $\mathrm{Y} .11$ EXAFS data of $\mathrm{Cp} * \mathrm{HFe}(\mathrm{CO})_{3}$ in $\mathrm{H}-\mathrm{Y}$ zeolite suggest the formation of a very similar fragment after heating under vacuum at $473 \mathrm{~K} .{ }^{19}$ These studies illustrate that iron carbonyl compounds are well suited for anchoring organo-iron fragments into the molecular sieve support by establishing a stable bond to the ring-shaped oxygen coordination sites in the cage system. Furthermore, this strategy allows us to control the siting of the immobilized metal fragment. Since the large neutral complexes cannot enter the smaller sodalite and double six-ring cages present in zeolite $Y$, they are confined to positions in the large supercage. In contrast, the traditional stepwise assembly of intrazeolite complexes from metal ions and small ligands such as $\mathrm{CO}$ relies upon preceding aqueous ion exchange and dehydration under drastic conditions. Thus, a large fraction of the metal is forced to migrate into the smaller cavities which are less desirable in the context of catalytic applications and which make characterization of the resulting mixture of intrazeolite products very

(18) Knox, G. R. Organometallic Compounds of Iron; Chapman and Hall New York, 1985; p 139

(19) Moller, K.; Bein, T. Unpublished results

(20) Edgell, W. F.; Wilson, W. E.; Summitt, R. Spectrochim. Acta 1963, 19,863

(21) (a) Bein, T.; Jacobs, P. A. J. Chem. Soc., Faraday Trans. 1 1983, 79, 1819. (b) Bein, T.; Jacobs, P. A. J. Chem. Soc., Faraday Trans. 1 1984, 80 , 1391 .

(22) Iball, J ; Morgan C. H. Acta Crystallogr. 1967, 23, 239.

(23) Seiler, p. Dunitz, J D Acta Crystallogr. 1979, B35, 1068

(24) Simon, F. E.: Lauher, J. W. Inorg. Chem. 1980, 19. 2338. 
difficult. The alternative procedure developed in the present work results in migration-stabilized fragments chemically anchored into accessible zeolite pores.

Acknowledgment. Acknowledgment is made to the donors of the Petroleum Research Fund, administered by the American
Chemical Society, and to the Sandia-University Research Program (DOE), for partial support of this research. The operational funds for NSLS beam line X-11A are supported by DOE Grant DEAS0580Er 10742 .

Registry No. [1], 12093-05-9; [3], 41853-19-4.

\title{
Extended X-ray Absorption Fine Structure Studies on the Structure Change of the $\mathrm{Al}_{2} \mathrm{O}_{3}$-Attached $\left[\mathrm{Co}^{\mathrm{II}}\right]_{4}$ Catalyst during a $\mathrm{CO}$ Oxidation Reaction
}

\author{
Kiyotaka Asakura and Yasuhiro Iwasawa* \\ Department of Chemistry, Faculty of Science, The University of Tokyo, Hongo, Bunkyo-ku, Tokyo 113, Japan \\ (Received: August 10, 1988; In Final Form: November 23, 1988)
}

\begin{abstract}
The dynamic structure change of active $\mathrm{Co}$ sites in the $\mathrm{Al}_{2} \mathrm{O}_{3}$-attached $\left[\mathrm{Co}^{11}\right]_{4}$ catalyst derived from $\mathrm{Co}_{2}(\mathrm{CO})_{8} / \mathrm{Al}_{2} \mathrm{O}_{3}$ in the course of the catalytic $\mathrm{CO}$ oxidation with $\mathrm{O}_{2}$ under atmospheric and high-pressure conditions was studied by means of in situ extended X-ray absorption fine structure (EXAFS). The $\mathrm{CO}_{4}$ ensemble composed of four adjacent Co monomers $(\mathrm{Co}-\mathrm{O}=0.197 \mathrm{~nm})$ as a local structure was converted to the oxygen-bridged $\mathrm{Co}_{0}$ dimer structure with $\mathrm{Co}-\mathrm{O}=0.196 \mathrm{~nm}$ and $\mathrm{Co}-\mathrm{Co}=0.330 \mathrm{~nm}$ in the reaction with $\mathrm{O}_{2}$. The bridged oxygen readily reacted with weakly adsorbed $\mathrm{CO}$ to produce $\mathrm{CO}_{2}$, the original $\mathrm{CO}_{4}$ ensemble structure composed of four adjacent $\mathrm{Co}$ monomers being recovered. The catalytic oxidation of $\mathrm{CO}$ with $\mathrm{O}_{2}$ at $273 \mathrm{~K}$ proceeds by a two-stage reaction mechanism involving the dissociative adsorption of $\mathrm{O}_{2}$ and the subsequent reaction with $\mathrm{CO}$, in conjunction with the structure change between the Co monomer structure and the Co dimer structure.
\end{abstract}

\begin{abstract}
The majority of studies on the reaction mechanisms for the solid catalysts has been carried out by means of the reaction kinetics, tracer techniques using an isotope in the reactants, and the identification of surface adsorbed species including reaction intermediates by means of IR, NMR, ESR, etc. However, in many of these studies the change of the surface structure of the active site and its dynamic change during the catalytic reaction, the knowledge of which is important for a complete understanding of catalytic reactions, are beyond the scope of the search. Recent developments in electron spectroscopies provide direct information on physical properties such as surface composition, surface structure, and electronic states, as well as on chemical phenomena such as adsorption and reaction on single-crystal surfaces. ${ }^{1}$ However, these techniques require ultrahigh-vacuum (UHV) conditions, which are too different from real catalytic reaction conditions. This restriction prevents in situ observation of solid surfaces under reaction conditions. Some studies have shown that static surface structures and reaction mechanisms in vacuo are entirely different from dynamic ones under reaction conditions. ${ }^{2-6}$ Thus, the direct observation of the active structures of solid surfaces during catalysis is of great importance for an understanding of the reaction mechanisms and the origin of catalysis and also to improve or to design better solid catalysts by this fundamental knowledge.
\end{abstract}

EXAFS (extended X-ray absorption fine structure) has such prominent features that it can give direct information about the local structure around an X-ray absorbing atom without the requirements of long-range ordered structure and UHV conditions. ${ }^{5,7-9}$ Thus EXAFS is a powerful tool for the determination

(1) King, D. A.; Woodruff, D. P. The Chemical Physics of Solid Surfaces and Heterogeneous Catalysts; Elsevier: Amsterdam, 1982; Vol. 4 24

(2) Zaera, F.; Gellman, A. J.; Somorjai, G. A. Acc. Chem. Res. 1986 19.

(3) Imbihl, R.; Cox, M. P.; Ertl, G. J. Chem. Phys. 1986, 84, 3519

(4) Wang, T.; Lee, C.; Schmidt, L. D.; Surf. Sci. 1985, 163, 181

(5) Van't Blik, H. F. J.; Van Zon, J. B. A. D.; Huizinger, T.; Vis, J. C.; Koningsnerger, D. C.; Prins, R. J. Phys. Chem. 1983, 87, 2264.

(6) Nishimura, M.; Asakura, K.; Iwasawa, Y. Int. Congr. Catal., Proc. 9th $1988,4,1842$. of surface structures of metal catalysts in the presence of reactant gas even at high pressures.

Conventional supported metal catalysts usually contain many kinds of metal atoms with different environments and reactivities, most of which may not directly participate in the catalytic reaction. The EXAFS analysis provides averaged information about these structures. Inorganic oxide attached metal catalysts prepared by the reaction between the surface $\mathrm{OH}$ groups of an inorganic oxide such as $\mathrm{SiO}_{2}$ and $\mathrm{Al}_{2} \mathrm{O}_{3}$ and organometallic complexes possess well-defined surface structures showing almost uniform reactivity. ${ }^{10,11}$ In this way one can overcome the equivocal and restricted spectroscopic information due to the surface heterogeneity and complexity of conventional catalysts. Recently we have carried out structure studies on a Mo dimer catalyst in the course of the oxidation of $\mathrm{C}_{2} \mathrm{H}_{5} \mathrm{OH}$ with $\mathrm{O}_{2}$ by means of in situ EXAFS.12 We revealed that the molybdenum dimers changed their local structures by ca. $0.04 \mathrm{~nm}$ laterally and by ca. $0.01 \mathrm{~nm}$ vertically during the reaction: The catalytic $\mathrm{C}_{2} \mathrm{H}_{5} \mathrm{OH}$ oxidation takes place in conjunction with the structural oscillation. ${ }^{12}$

The $\mathrm{Al}_{2} \mathrm{O}_{3}$-attached $\mathrm{Co}$ (II) cluster catalyst derived from $\mathrm{CO}_{2}(\mathrm{CO})_{8}$ showed a much higher activity than the conventional impregnated or ion-exchanged $\mathrm{Co} / \mathrm{Al}_{2} \mathrm{O}_{3}$ catalysts for the oxidation of $\mathrm{CO}$ with $\mathrm{O}_{2}{ }^{13,14}$ On the other hand, the $\mathrm{SiO}_{2}$-attached

(7) Sayers, D. E.; Stern, E. A.; Lytle, F. W. Phys. Rev. Lett. 1971, 27, 1204.

(8) Lytle, F. W.; Via, G. H.; Sinfelt, J. H. J. Chem. Phys. 1977, 67, 3831.

(9) Bart, J. C. J.; Vlaic, G. Adv. Catal. 1987, 35, 1.

(10) (a) Yermakov, Yu. I.; Kuznetov, B. N.; Zakharov, V. A. Catalysis by Supported Complexes; Elsevier: Amsterdam, 1981. (b) Ugo, R.; Psaro, R.; J. Mol. Catal. 1983, 20, 53. (c) Basset, J. M.; Choplin, A. J. Mol. Catal. 1983, 21, 95. (d) Gates, B. C.; Guczi, L.; Knozinger, H. Metal Cluster Catalysts; Elsevier: Amsterdam, 1986

(11) (a) Iwasawa, Y. Tailored Metal Catalysts; D. Reidel Publishing Co.: Dordrecht, The Netherlands, 1985 . (b) Iwasawa, Y. Adv. Catal. 1987, 35, 187.

(12) Jwasawa, Y.: Asakura, K.; Ishii, H.; Kuroda, H. Z. Phys, Chem. (Munich) 1985, 144, 105

(13) Iwasawa, Y.; Yamada, M.; Sato, Y.; Kuroda, H. J. Mol. Catal. 1984, 23,95

(14) Yamada, Y.; Iwasawa, Y. Nippon Kagaku Kaishi 1984, 1049. 